S100A8 is a strong inducer of activating FceRI and FceRIV through activation of TLR4 and drives FceR expression and severe cartilage destruction in antigen-induced arthritis.

\section{A102 ALARMIN S100A8 CAUSES SEVERE CARTILAGE DAMAGE IN ANTIGEN-INDUCED ARTHRITIS THROUGH TLR4 ACTIVATION AND UPREGULATION OF FCERI AND FCERIV}

P L E M van Lent,, L Grevers, ${ }^{1}$ R Schelbergen, ${ }^{1}$ A Blom, ${ }^{1}$ A Sloetjes, ${ }^{1}$ T Vogl, ${ }^{2}$ J Roth, ${ }^{2}$ W B van den Berg' ${ }^{1}$ Department of Rheumatology, Radboud University Nijmegen Medical Centre, Nijmegen, The Netherlands; ${ }^{2}$ Department of Dermatology, UKM, Munster, Germany

\subsection{6/ard.2010.1296270}

The 'alarmins' S100 A8 and A9 have been described not only as markers for inflammation but may also be involved in induction of erosive cartilage destruction. ${ }^{1}$ S100A8 represents the active form whereas S100A9 binds to S100A8, protecting the protein from degradation. The aim of the study is to identify the mechanisms of S100 involvement in severe cartilage destruction during antigen-induced arthritis.

Antigen-induced arthritis (AIA) was induced in knee joints of S100A8/A9-/- mice (myeloid cells also lack S100A8) and their wild-type (WT) controls and severe cartilage destruction was measured using immunolocalisation of VDIPEN neoepitopes and chondrocyte death. rS100A8 was injected into mouse knee joints, synovium was isolated and mRNA levels were measured using RT-PCR. M-CSF stimulated bone marrow macrophages were stimulated by rS100A8, rS100A9 and S100A8/S100A9 complexes and mRNA and protein levels of FceR were measured using RT-PCR and FACS analysis.

AIA was induced in control and S100A9-deficient mice. Cartilage proteoglycan loss at day 2 was not different in the knockouts, but VDIPEN expression and severe surface erosion was markedly suppressed at day 7 . To identify the mechanism of S100 involvement, the authors injected rS100A8 $(5 \mu \mathrm{g})$ into the knee joint of normal mice. This caused only mild joint inflammation, but pronounced upregulation of activating FceRI and FceRIV (mRNA levels 64-fold and 256fold, respectively). The authors know from earlier studies that FceRI and FceRIV are crucial factors in immune complex-mediated cartilage damage in this model. In vitro analysis with bone marrow-derived macrophages confirmed this upregulation by S100A8 and showed profound increases of type I and IV protein expression with FACS analysis. S100A9 or S100A8/S100A9 complex were less potent in stimulating activating FceRI and FceRIV. Similar studies with a granulocyte cell line did not show any upregulation of Fc receptors, underlining the specificity for macrophages. Of great interest when bone marrow cells were taken from TLR4-/- mice, S100A8-mediated upregulation of FceRI and FceRIV was virtually absent, indicating that S100A8 caused this effect through TLR4.

TLR4 and activating FceR were highly expressed in inflamed synovium taken at day 7 AIA whereas in S100A9-/- knockout activating FceR were strongly diminished, underlining that S100A8/S100A9 regulates FceR expression during AIA. 